
absolwentka filologii polskiej na Uniwersytecie Kardynała

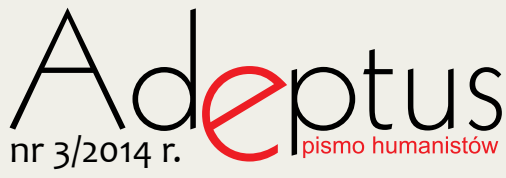
Stefana Wyszyńskiego. W latach 2010-2013 pracowała jako asystent w Katedrze Współczesnego Języka Polskiego na Wydziale Nauk Humanistycznych UKSW. Była prezesem, a następnie opiekunem naukowym Koła Językoznawczego WNH UKSW. Jej zainteresowania badawcze to: składnia, semantyka, pragmatyka, lingwistyka kulturowa, antropologia lingwistyczna

\title{
"O czym nie można mówić, o tym trzeba milczeć"? - obszary językowo tabuizowane w tekstach prasowych z okresu żałoby narodowej po śmierci Józefa Piłsudskiego
}

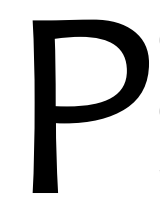

ojęcie tabu, stawiane coraz częściej w centrum zainteresowań badaczy różnych dyscyplin naukowych, pierwotnie rozumiano jako zakaz dotykania pewnych przedmiotów, zwierząt czy osób oraz mówienia o nich, a także same te przedmioty, zwierzęta lub osoby (coś/ktoś mógł być Tabu) (Tyrpa, 2009, s. 14)․ Według Encyklopedii językoznawstwa ogólnego [EJO] tabu językowe to ,zakaz posługiwania się pewnymi wyrazami lub wyrażeniami w danej społeczności językowej”, co w konsekwencji prowadzi do zastępowania owych zastrzeżonych wyrażeń innymi w celu złagodzenia treści przekazu (por. EJO, s. 591). Jest to tzw. „tabu w planie wyrażania”, dotyczące zakazu używania określonych słów, nierozerwalnie związane z eufemizowaniem². Interdyscyplinarne badania nad tabu zaowocowały także zwróceniem uwagi na zagadnienie „tabu w planie treści”, odnoszące się do tzw. „tematów tabu”, czyli pewnych aspektów rzeczywistości, o których nie należy mówić w ogóle.

Wszystkie dyscypliny naukowe zajmujące się tematyką tabu podkreślają jego podstawowy wymiar, tzn. językowy charakter tabuizowania związany z funkcją magiczną języka, różniąc

\footnotetext{
1 Szczegółowo tematykę tabu w aspekcie kulturowym i lingwistycznym, zarówno w zakresie teorii, jak i egzemplifikacji materiałowych, omawia tom 21 serii „Język a kultura”. Zob. (Dąbrowska (red.), 2009).

2 Eufemizm rozumiem jako wyraz lub związek frazeologiczny zastosowany w celu uniknięcia użycia takiego środka leksykalnego, który z przyczyn estetycznych, kulturowych czy cenzuralnych uważany jest za nieprzyzwoity lub drastyczny (EJO, s. 148).
} 
się głównie w zakresie motywacji (przyczyn) powstawania tabu. Upatrywano ich kolejno w motywacjach silnie religijnych (tzw. tabu pierwotne), psychologicznych (tabu jako prastary zakaz narzucony z zewnątrz, np. przez jakiś autorytet, i skierowany przeciw najsilniejszym żądzom człowieka (zob. Freud, 1993, s. 53), towarzyskich, moralnych, społecznych, etycznych i etykietalnych (tabu nowożytne), by wXX w. zaowocować np. zjawiskiem poprawności politycznej (PC - political correctness) (zob. Szymoniak, 2009, s. 106). W kontekście żałoby narodowej po śmierci Józefa Piłsudskiego - otaczanego już za życia swoistym kultem, w którego podtrzymywaniu nierzadko wykorzystywano mechanizmy tabuizacji - warte przytoczenia wydają się również rozważania Mircei Eliadego: „Na ogół jest lub staje się tabu każdy przedmiot, czynność lub osoba, która ma w sobie jakąś siłę o mniej lub więcej określonej naturze na skutek własnego sposobu bycia [podkreślenie moje - M.R.] albo nabywa ją w wyniku jakiegoś przełamania płaszczyzny ontologicznej" (Eliade, 1966, s. 21).

Wprowadzenie samego słowa tabu do języków europejskich (nie ma ono adekwatnego odpowiednika w żadnym z nich) zaowocowało kolejnymi zmianami znaczeniowymi i przeniesieniem najbardziej wyrazistego komponentu znaczeniowego, czyli „,nietykalności”, na znaczenie przenośne - „zakazane”, tzn. „nietykalne słowem”, a także oderwaniem od pierwotnego kontekstu religijno-magicznego. Etyczno-lingwistyczny nakaz (a właściwie zakaz) Wittgensteinowski zawarty w tytule tekstu zwraca także uwagę na kwestię niezmiernie istotną w kontekście tabu, mianowicie na przemilczenie. Okazuje się bowiem, że - przynajmniej w przypadku interesującego mnie zagadnienia żałoby narodowej - milczenie absolutne wcale nie jest pożądane. Do tego wątku powrócę w dalszej kolejności.

Na potrzeby moich analiz przyjmuję możliwie szeroką definicję tabu zaproponowaną przez Annę Dąbrowską: „,tabu jest zjawiskiem kulturowym obejmującym wszystko to, co jest objęte zakazem społecznym (czasem również prawnym); są to zachowania, których nie należy praktykować, i tematy, jakich nie należy poruszać w danej społeczności (nie wypada o nich mówić), ponieważ są uznawane za wstydliwe, niebezpieczne, kontrowersyjne, przykre lub niemoralne." (Dąbrowska, 2008, s. 175).

W niniejszym artykule chciałabym zająć się jednym z podstawowych obszarów, który od zawsze podlegał tabuizacji, czyli tabu związanym z mówieniem o śmierci. Moim zamiarem nie jest jednak rozważanie śmierci w wymiarze ogólnoludzkim, a jedynie w kontekście żałoby narodowej. Odmienny jest wtedy przede wszystkim charakter uroczystości żałobnej - zmienia się z prywatnej na oficjalną o państwowym i międzynarodowym zasięgu, co w konsekwencji sprawia, że obszary tabuizacji podlegają wzmocnionym (bo również instytucjonalno-prawnym) restrykcjom, a każde słowo drukowane na szpaltach gazet poddawane jest ustawicznej społecznej „,cenzurze”. Moje rozważania chciałabym oprzeć 
na przykładzie żałoby narodowej ogłoszonej po śmierci Józefa Piłsudskiego. Postaram się omówić zarówno tabu w planie wyrażania, jak i w planie treści.

Podstawę materiałową stanowią teksty prasowe o charakterze odredakcyjnym (a więc z wyłączeniem innych gatunkowo tekstów, jak np. orędzie prezydenta lub kazania pogrzebowe przedrukowywane w prasie czy teksty autorskie, np. felietony lub wspomnienia) drukowane w okresie trwania żałoby powszechnej, czyli od 13 do 18 maja 1935 r. (żałoba obowiązująca wojskowych i urzędników trwała 6 tygodni). Te ramy czasowe przyjęłam jako obowiązujące dla badanych dzienników, tzn.: „ABC: nowiny codzienne” (dalej-ABC), ,,Kuriera Warszawskiego” (KW), ,,Kuriera Porannego” (KP), , "llustrowanego Kuriera Codziennego” (IKC; wydanie krakowskie), ,,Gazety Warszawskiej” (GW), ,,Czasu”(Cz), „,Gazety Polskiej” (GP), ,,Robotnika” (R) oraz tygodnika ,Nasz Przegląd” (NP). Wykorzystano również album pamiątkowy „Gdy wódz odchodził w wieczność" (GWOWW). Jest to próbka reprezentatywna zarówno pod względem nakładu, jak i zasięgu terytorialnego oraz prezentowanej opcji światopoglądowej. Rynek prasowy w dwudziestoleciu międzywojennym był bardzo rozbudowany i zróżnicowany (w latach 30. roczna liczba tytułów wahała się od 2250 do 2700), jednak zmieniał się dynamicznie i wiele tytułów wydrukowano jedynie w kilku numerach, a aż 1/3 tytułów ukazywała się nie dłużej niż dwa lata. Tymczasem badane przeze mnie dzienniki istniały na rynku od wielu lat i/lub miały wysokie nakłady. Wspomniane tytuły reprezentują również najważniejsze ówczesne opcje światopoglądowe: narodowo-demokratyczną (GW, KW, ABC, a także lokalna „Gazeta Radomska" [GR]), konserwatywną (Cz), sanacyjną (GP), lewicowo-socjalistyczną (R) i żydowską (NP). IKC oraz związany z tym domem prasowym tygodnik „Światowid” (Ś) to przykłady prasy popularnej o orientacji prorządowej - stanowią podstawowe źródło cytatów, ponieważ nakład wydawnictw IKC przekraczał nakład pozostałych dzienników razem wziętych (200 tys. egz. IKC w porównaniu z ok. 30-tysięcznym nakładem każdego z pozostałych dzienników). Przykładem prasy popularnej w wydaniu warszawskim jest „Dobry Wieczór - Kurier Czerwony” (KCz).

\section{Tabu w kontekście żałoby narodowej}

W obliczu śmierci wybitnych jednostek, po których ogłasza się żałobę narodową, obserwujemy dwoistość postaw wobec śmierci - z jednej strony jest to naturalna żałoba po stracie konkretnego człowieka, zidentyfikowanego z imienia i nazwiska, z drugiej strony - jest to także żałoba o charakterze oficjalnym, „sformalizowana”; żałoba po osobie postrzeganej przez pryzmat pełnionej roli społecznej. Także $w$ kontekście interesującego mnie zagadnienia tabuizacji związanej ze śmiercią dostrzegalne jest wspomniane wyżej 
zróżnicowanie. W zakresie tabu związanego z żałobą w wymiarze indywidualnym szczególnym zabiegom tabuizującym podlegają zwłaszcza zagadnienia cielesności zmarłego i samego faktu śmierci, zaś w kontekście żałoby oficjalnej - również pewne etapy działalności politycznej (w przypadku Józefa Piłsudskiego są to głównie przewrót majowy oraz forma rządów sprawowanych przez niego w ostatnich latach życia). Pierwszy rodzaj tabu narzucany jest przez ogólne normy społeczne wypracowane na gruncie danej kultury, drugi ma motywację „,instytucjonalną”, dotyczy bowiem tego, co było przedmiotem kontrowersji już za życia danej osoby.

\section{XX-wieczne zwroty „Do trupa”}

Jak wskazuje Alfonso di Nola, włoski historyk religii: „W językach zachodnich człowiek definitywnie pozbawiony życia określany jest jako cadavere (trup), od starołacińskiego cadaver, często zastępowanego eufemistycznym corpus (ciało)" (di Nola, 2006, s. 243). Unikanie verbum proprium (trup) znajduje potwierdzenie $w$ badaniach materiałowych ${ }^{3}$ - określenie trup jest praktycznie nieobecne w oficjalnym dyskursie żałobnym. Jest to chyba najsilniej eufemizowany leksem w kontekście mówienia o śmierci, ponieważ - jak zauważa w swoim artykule dotyczącym tabuizowania śmierci Anna Jasik: „,Wprowadza on pojęcie obcości i wrogości (...) wprowadza dystans, który nie występuje np. w słowie nieboszczyk, zmarły czy zwłoki (por. drogie nam zwłoki), nazwa ta wskazuje, że martwe ciało nie jest już kimś, a stało się czymś" (Jasik, 2009, s. 185). Tymczasem w tekstach prasowych powstałych po śmierci Piłsudskiego zmarły jest nadal „,kimś”, jest wręcz „ożywiany”, cały czas działa, wykonuje zwyczajowe - te, co za życia - obowiązki (przyjmuje ostatnią defiladę, składa żołnierski meldunek przed Bogiem), a w tekstach silnie retorycznych nawet przemawia (,,Kazałeś mi Panie cierpieć dla narodu mojego (...) znosić obelgi wrogów, i uczyniłem to wedle najlepszej swojej woli. Kazałeś mi Panie naród prowadzić po szlakach niepodległości, karać jego grzechy, poskramiać nieprawości i uczyniłem to wszystko.” [Ś, 19 maja]); staje się także odbiorcą deklaracji („,Przyrzekamy ci, Marszałku (...)", [Ś, 26 maja]).

W tekstach prasowych najczęściej pojawiają się eufemizmy ciało i zwłoki, zarówno w gatunkach czysto informacyjnych, jak i publicystycznych. W tych drugich zwykle obudowane są retorycznie funkcjonalnymi przydawkami przymiotnymi lub rzeczownymi

\footnotetext{
${ }^{3}$ Jest to zabieg tak częsty, że istotnym niedopatrzeniem wydaje się nieumieszczenie eufemizmów dotyczących zmarłego w stanowiącej swojego rodzaju kompendium wiedzy na temat eufemizmów pracy Anny Dąbrowskiej pt. Eufemizmy wspótczesnego języka polskiego oraz w redagowanym przez nią Słowniku eufemizmów polskich.
} 
(„,Najdroższe Ciało” [Ś, 26 maja]; ,spoczywa w otwartej jeszcze trumnie ciało Marszałka Piłsudskiego” [GP, 16 maja]; „,Drogie Zwłoki” [Ś, 26 maja]; , ,u zwłok swego Wskrzesiciela” [Cz, 14 maja]; , u stóp Zwłok swego Wodza” [KCz, 14 maja]); w przeciwieństwie do tekstów informacyjnych typu: „,Eksportacja zwłok śp. Marszałka Piłsudskiego” [Cz, 17 maja]; „Eksportacja zwłok” [ABC, 16 maja]. W dalszej kolejności dość często pojawia się zmarły, zwłaszcza w tekstach wspomnieniowych czy biograficznych, ponieważ w przeciwieństwie do ciała i zwłok, które podkreślają fizyczność, a więc „,przedmiotowy” wymiar człowieka po śmierci, wyraz zmarły ma najbardziej osobowy charakter ze wszystkich eufemizmów, a jednocześnie nie jest nacechowany archaicznie jak np. nieboszczyk („spadkobierców myśli politycznej zmarłego” [GR, 19 maja]; „,duchem Zmarłego” [GP, 15 maja], ,,hołd ostatni Wielkiemu Zmarłemu” [KCz, 14 maja] oraz również dość niezręczne stylistycznie „Jeszcze w piątek Zmarły interesował się żywo rozmowami (...)" [ABC, 14 maja].

Pojawiają się także, choć wyraźnie rzadziej, takie określenia jak: szczątki („najdroższemi szczątkami wodza”; „śmiertelne szczątki” [Ś; 26 maja]; „śmiertelne szczątki”, „,doczesne szczątki” [IKC, 15 maja]; ,'Śmiertelne szczątki Twórcy niepodległości” [Cz, 14 maja], „śmiertelne szczątki Wodza” [GWOwW]), prochy (,składa hołd prochom swego Wodza” [IKC, 15 maja]; „Stolica królów czeka na prochy Wodza” [KCz, 17 maja]), a także bardziej osobliwe, np. cienie („Rolnictwo w hołdzie cieniom Marszałka Piłsudskiego” [Cz, 16 maja]), lub rozbudowane konstrukcje, np. odchodzący na wieki („,pożegna Wielkie Serce odchodzącego na wieki” [Ś, 26 maja]. Szczególnie ważne wydaje się przesunięcie semantyczne i stylistyczne, jakie dokonało się w przypadku leksemu szczątki. Do połowy XX w. funkcjonował on (głównie we frazeologizmie ‘doczesne/śmiertelne szczątki czyjeś’ [por. SJP Dor. i SJP Warsz.]) jako eufemistyczne określenie zwłok, co korespondowało z jego podstawowym znaczeniem - 'szczątek', czyli ‘początek lub koniec, kres’ [por. SJP War.]. Współcześnie zaś leksem ten sam stał się elementem tabuizowanym. Wiąże się to ze zmianą znaczenia leksemu 'szczątek', a dokładniej - z zawężeniem zakresu jego użycia. Wynika to z zespolenia znaczeń dwóch osobnych jednostek (szcząt - 'odrobina pozostała, ślad, zabytek, ułamek pozostały, resztki nieznaczne, strzępy pozostałe' [SJP War.] i szczątek) w jedno (szczątek). Jak podaje WSJP, ‘szczątek' to 'resztka czegoś zniszczonego, rozbitego', cecha i właściwość materii. Oczywiście przykłady użycia pozwalają na odniesienie do człowieka, ale jest ono w tej chwili dodatkowo ograniczone - 'szczątkami' określimy jedynie zwłoki w zaawansowanym stadium rozkładu lub rozczłonkowane. Właśnie ze względu na to bezpośrednie, wręcz drastyczne odniesienie do „materialnego” wymiaru zmarłego, a więc jego zdepersonalizowanie, obecnie w tekstach nienacechowanych stylistycznie w ogóle unika się używania określenia 'szczątki', głównie ze względów grzecznościowych. 
Wyjątkowego znaczenia nabiera stosunek do ciała przejawiający się w eufemizmach stosowanych na opisanie zwłok marszałka po uroczystości złożenia trumny na Wawelu, co stanowiło symboliczne zrównanie Piłsudskiego z królami polskimi i wpisanie go w szereg odniesień historyczno-kulturowych (tytuł z okładki KCz z dnia 18 maja 1935 r.: „Król-Duch na Wawelu”). Od tego czasu ciało marszałka to już najdroższe narodowe relikwie [Ś; 26 maja] („,Położono na lawecie najdroższe relikwie” [GWOwW]). Ta szczególna sakralizacja ciała służy podtrzymywaniu pieczołowicie budowanego kultu jednostki. Jej przejawy były obecne już za życia marszałka (np. IKC w drugim tygodniu żałoby przywołuje opowieść o tym, jak legioniści rzucili się zbierać włosy marszałka, kiedy skorzystał on z usług koszarowego fryzjera, aby móc je zachować jako pewnego rodzaju relikwie), jednak uległy spotęgowaniu po śmierci. Współgrają z nimi liczne zabiegi symboliczne podtrzymujące wizerunek niezłomnego wodza, człowieka ze stali, nieugiętego i niezniszczalnego (np. wygląd zwłok - mundur marszałkowski, w ręku ryngraf z Matką Boską Ostrobramską, pierś przepasana wstęgą orderu Virtuti Militari, a „,w nogach buława marszałkowska, szabla i szara, ukochana przez Wodza maciejówka" [Ś, 19 maja]). Znamienne jest także samo otwarcie trumny (,Powzięto decyzję otwarcia trumny” [IKC, 16 maja]) na czas publicznego wystawienia zwłok oraz jej przeszklenie, aby ci, którzy przyjdą pożegnać marszałka, ,,zanieśli żywe wspomnienie rysów charakterystycznej, a tak drogiej twarzy Odnowiciela Polski i Wodza Narodu" [Ś, 26 maja], co jest jednym z podstawowych działań służących tworzeniu kultu zmarłych (por. Ariès, 1989, s. 497). Podtrzymywaniu tego kultu służą także warte odnotowania eufemizmy katafalku („,tron duchowego Króla Polaków” [IKC, 16 maja]) czy konduktu pogrzebowego - był to „ostatni szlak”, „,marsz szlakiem wieczności” [IKC, 16 maja], a zarazem „odwrócony szlak kadrówki” [IKC, 16 maja], który zmarły przemierzał za życia jako dowódca legionów.

Oczywiście, eufemizowana jest także sama śmierć - większość nagłówków na okładkach dzienników z 13 maja unika czasownika umrzeći informuje, że marszałek nie żyje (jedynie GW i KW zdecydowały się na formułę „,Zgon marszałka Piłsudskiego” [GW, KW, 13 maja]). Poza tym dominują zleksykalizowane metafory śmierci jako snu („Ale Marszałek śpi”; „,do wiecznego, nieprzerwanego snu” [Ś, 19 maja]; , gdy Marszałek śpi snem wiecznym w wielkim salonie Belwederu” [IKC, 13 maja]; ), o dejścia/z ejścia (,zszedł z tego świata” [GP, 15 maja]; , odszedł w ostatnią pielgrzymkę Ojciec Ojczyzny” [Cz, 14 maja]; „,Odszedł człowiek wielki” [ABC, 14 maja], „Król-Duch narodu odszedł w zaświaty” [IKC, 18 maja]), zgaśnięcia (interpretowanego dwojako: jako zgaśnięcie płomienia życia - „Zgasł ten, który był wcieleniem Polski" [IKC, 15 maja] - lub jako składnik metafory, wykorzystywanej później często przy okazji śmierci innego wodza, czyli metafory gasnącego słońca: 
„zgasło nad nią [ojczyzną - M.R.] Wielkie jej Słońce” [IKC, 18 maja]), czy zakończenia/ końca („,zakończył życie”|"życie zakończył” [IKC, 13 maja]; „,...) że koniec nastąpi tak szybko" [ABC, 14 maja]). Innymi często wykorzystywanymi eufemizmami były metonimiczne zwroty zamknąć oczy (,Marszałek zamknął oczy o godz. 20.45 wiecz.”, ,,zamknął oczy na zawsze” [IKC, 13 maja]; „,Bóg zamknął oczy człowieka (...)” [KW, 13 maja] oraz przestało bić serce („,Przestało bić w narodzie wielkie serce, zgasły na zawsze oczy (...)” [GWOwW]) - w obydwu przypadkach eufemizowanie odbywa się poprzez odniesienie do przyczynowo-skutkowych sytuacji towarzyszących śmierci. Interesującym eufemizmem sensu stricto, a więc niezakorzenionym, niezleksykalizowanym, jest katastrofa: „,choć ogólnie spodziewano się katastrofy” [Ś, 19 maja]; ,,(...) nie ukrywając jednak przewidywania, że katastrofa nastąpi raczej przed tym terminem" [GP, 15 maja]. Często eufemizowano także śmierć jako „zasłużony odpoczynek”, co niewątpliwie miało na celu ułatwienie pogodzenia się osobom przeżywającym stratę z faktem śmierci i stwarzało doskonałą okazję do podkreślania, a niekiedy hiperbolizowania ciężaru odpowiedzialności, jaki spoczywał na marszałku („,odpoczywając w prostej dębowej trumnie po trudach życia” [Ś, 26 maja]; , ,czeka go zasłużony odpoczynek” [Ś, 19 maja]). Podobną funkcję spełniają eufemistyczne metafory śmierci jako snu (por. Dąbrowska, 1993, s. 97).

Wskazane powyżej eufemizmy cechuje styl podniosły oraz wysoki stopień skonwencjonalizowania, co jest charakterystyczne dla wielu gatunków żałobnych (np. nekrolog, kondolencje). Wynika to po części z zasad polskiej grzeczności językowej, która bardziej ceni milczenie niż nadmierną ozdobność stylistyczną języka w czasie żałoby, po części zaś z długiej tradycji wyrażania żalu w europejskim kręgu kulturowym (metafora śmierci jako snu jest wspólna większości języków europejskich - (zob. Dąbrowska, 1993, s. 95-96; Alla, Burridge, 2006, s. 225). Należy jednak zwrócić uwagę na wyraźne zróżnicowanie stylistyczne powyższych eufemizmów, istnieje bowiem znaczna różnica między wykorzystaniem tropów stylistycznych, charakterystycznych dla języka artystycznego, a użyciem eufemizmów koniecznych ze względów grzecznościowych, jak: ciało, zwłoki, nie żyje. Przynależą one do dwóch odmian stylu dziennikarskiego - poetyckie metafory (śmierć jako sen/odpoczynek/zgaśnięcie) pojawiają się w dłuższych tekstach publicystycznych o wyraźnie pozytywnym zabarwieniu emocjonalnym, w znakomitej większości w czasopismach reprezentujących nurt prorządowy, z kolei określenia bardziej formalne funkcjonują zwykle w tekstach informacyjnych, relacjonujących plan, a następnie przebieg uroczystości żałobnych.

Podsumowując rozważania dotyczące tabu i eufemizowania śmierci oraz obszarów z nią związanych w czasie trwania żałoby narodowej po śmierci Piłsudskiego, należy także zwrócić 
uwagę na ich funkcję retoryczną, a ściślej - perswazyjną. Wykorzystywane eufemizmy służą nie tyle zachowaniu delikatności i postawy etycznej wobec jednostkowej śmierci, ile raczej przygotowują grunt pod dalsze zabiegi retoryczne służące usankcjonowaniu utrzymania, a nawet wzmocnienia kultu jednostki, z jakim mieliśmy do czynienia za życia zmarłego. Dzieje się tak już od poziomu potocznego przekonania, że „,nie należy źle mówić o zmarłych”, aż do zręcznego wykorzystywania pojawiających się tematów tabu, czyli tabu w planie treści.

\section{Tabu a cenzura}

W kontekście kształtowania się tematów tabu szczególnie istotne są relacje między cenzurą a tabu. Wydaje się, że pominięcie tematu cenzury w tekstach dotyczących tabu jest wyraźnym brakiem, zwłaszcza przy uwzględnianiu w definicjach - zarówno eufemizmu, jak i tabu - tego typu motywacji. Związek między cenzurą a tabu jest implicite wpisany w samo pojęcie tabu. Jak wskazuje Anna Dąbrowska:

Tabu występujące swego czasu na Polinezji określa się jako [...] obrzędy religijne ustanowione dla celów politycznych. Tabu nakładano na wodzów (władców), królów, kapłanów i bogów tworzących nierozerwalną teokrację. Odpowiednio wykorzystane tabu pozwalało na kontrolowanie sytuacji ekonomicznej i było kamieniem węgielnym systemu społecznego. Jednak tabu było nie tylko podstawowym narzędziem utrzymującym dyscyplinę społeczną na niższych szczeblach rozwoju kultury, lecz stało się zalążkiem (seed-bed) religii (dokładnie - personal religion). (...) Tabu stawało się czynnikiem umacniającym porządek społeczny, wzmacniającym jedność społeczeństwa, było wzorcem postępowania (...) było «jedną z głównych norm regulujących stosunki społeczne i ekonomiczne»". (Dąbrowska, 1993, s. 18).

Cytat ten wyraźnie wskazuje na związek tabu z polityką, a tym samym z jednym z jej możliwych instytucjonalnych przejawów - z cenzurą. Temu właśnie służyła i służy obecnie tabuizacja - jest to cenzurowanie określonych zachowań (w tym zachowań językowych) w celu utrzymania i umacniania porządku społecznego i przestrzegania norm wypracowanych na gruncie danej kultury. Badacze podkreślają także istnienie odpowiedniej motywacji powstawania tego typu tabu, tzw. motywacji ideologicznej: „Występuje ona [motywacja ideologiczna - M.R.] wówczas, kiedy sposób wyrażania dostosowuje się do wyznawanej idei, np. równości, postępu, pokojowego współżycia itp. (...) Motywacja ideologiczna pojawia się przede wszystkim na polu polityki międzynarodowej oraz polityki wewnętrznej poszczególnych państw" (Dąbrowska, 1993, s. 28-29). Ten właśnie rodzaj motywacji zaowocował w XXI w. pojęciem ,,poprawności politycznej” i wyznaczeniem kolejnych obszarów tabu, jednak jak ilustrują chociażby 
przytoczone powyżej cytaty, jest on wpisany - implicytnie lub eksplicytnie - w samą ideę państwowości. Jak zauważają autorzy pracy Forbidden Words: Taboo and the Censoring of Language: „Słowo tabu odnosi się do zakazanego zachowania, a tabuizowane zachowanie jest przedmiotem cenzury." (Allan, Burridge, 2006, s. 237). Stwierdzenie to dobrze obrazuje zależność między tabu a cenzurą - zachowania, na które nakładamy tabu, stają się niejako automatycznie obiektem szeroko rozumianej cenzury. Inaczej mówiąc - cenzura obejmuje swym zasięgiem te zachowania, na które w danej kulturze nałożono tabu.

Ważne w tym kontekście jest oczywiście wskazanie na dwa rodzaje cenzury - na cenzurę wewnętrzną, indywidualną, tzw. autocenzurę, oraz na cenzurę zewnętrzną - społeczną lub instytucjonalną (prewencyjną lub represyjną). W okresie żałoby narodowej możemy zaobserwować przejawy obydwu rodzajów cenzury, przy czym autocenzura odnosi się głównie do sposobu mówienia o śmierci, a więc omówionego powyżej problemu eufemizowania. Dużo istotniejsza jest jednak zewnętrzna cenzura społeczna dotycząca naruszania tematów tabu lub niewłaściwego zachowania się w obliczu żałoby narodowej. Publiczny charakter uroczystości żałobnych sprawia, że zakazy towarzyszące prywatnej komunikacji w obliczu śmierci (takie jak zakaz mówienia źle o zmarłym czy poruszania nieprzyjemnych faktów z jego biografii) ulegają multiplikacji, ponieważ podlegają nie tylko osądowi najbliższych zmarłego, ale całego społeczeństwa. Za przełamywanie tego społecznie akceptowanego tabu grozi silny ostracyzm, z którym w obliczu śmierci Piłsudskiego spotkała się np. „Gazeta Warszawska". Jako jedyny tytuł po śmierci marszałka nie ukazała się ona w żałobnej szacie graficznej. Spowodowało to ostrą reakcję Związku Wydawców, Dzienników i Czasopism R.P., który potępił i wykreślił „Gazetę Warszawską” z listy członków oraz zwrócił się z prośbą o niekolportowanie tytułu z powodu „,braku należytego szacunku wobec majestatu śmierci śp. Marszałka Piłsudskiego ze strony «Gazety Warszawskiej»” [,IKC”, 16 maja]. Dotyczyło to zarzutów wobec okładek z 13 i 14 maja - zwłaszcza pierwszą z nich uznano za szczególnie obraźliwą, gdyż zamieszczono na niej (jak tłumaczyła redakcja, przez pomyłkę) zdjęcie uśmiechniętego ministra spraw zagranicznych Francji w pociągu do Moskwy. Usunięcie ze Związku postulowano ,wobec wysoce nieobywatelskiego stanowiska Wydawnictwa ,Gazety Warszawskiej”, która w obliczu Ogólnonarodowej żałoby z powodu śmierci Wielkiego Wodza Pierwszego Marszałka Polski śp. Józefa Piłsudskiego wyłamała się z ogólnej żałoby (...)" [Cz, 18 maja]. Potępienie społeczne miało także wymiar praktyczny - zaprzestano kolportowania wydawnictwa, co doprowadziło do upadku tytułu; ostatni numer ukazał się 17 maja (od 26 maja gazeta ukazywała się jako „Warszawski Dziennik Narodowy”).

Inny przykład obrazujący, co spotyka tych, którzy łamią tabu i pozwalają sobie na krytyczne uwagi, to reakcja na słowa pojawiające się na łamach prasy czeskiej i litewskiej. Jakie słowa? 
Nie dowiadujemy się tego, bowiem nie jest istotne, co napisano, ale jednoznaczne potępienie i surowa ocena: „Czesi i Litwini nie uszanowali nawet majestatu śmierci. (...)Wyciu czeskich hjen zawtórowałjedynie skowyt litewskiego szakala" [IKC, 24 maja]. To szczególny rodzaj manipulacji, ponieważ bardzo mało prawdopodobne jest, aby przeciętny odbiorca IKC dotarł do tekstów z ,"Lidovych Novin” oraz „Ducha Czasu” i sam mógł ocenić obraźliwy ton artykułów - w pamięci miała pozostać wyraźna krytyka jako przestroga przed ewentualnym przełamaniem zakazu mówienia źle o zmarłym. Jest to o tyle znamienne, że ogólnie przedrukowywano fragmenty prasy zagranicznej; powstawały nawet specjalne rubryki „echa żałoby z kraju i ze świata”. Co więcej, przedrukowywano również depesze kondolencyjne z Litwy i Czech.

Ważnym elementem autocenzury społecznej jest także świadomość owych zakazów, często wypowiadana wprost przez prasę różnych opcji: „Nie poruszając nad trumną Zmarłego Wodza Narodu żadnych spraw politycznych (...)” [„,IKC”, 16 maja]; „,Nie czas i nie miejsce nad trumną rozwodzić się (...) [,„Gazeta Radomska”, 19 maja]; „Nie będę o tem pisał nad otwartą mogiłą” [„,Robotnik”, 19 maja]. Jednak zabiegi takie są szczególnym nośnikiem perswazji, narażonym na nadużycia i hipokryzję. Jak słusznie wskazuje Tadeusz Zgółka: ,chodzi o perswazję realizowaną z wykorzystaniem obszarów zakazanych, zwłaszcza przy zastosowaniu chwytów metatekstowych, w których expressis verbis nazywa się obszary objęte tabuizacją, dodając zresztą hipokrytycznie, że oczywiście nie będzie o nich mowy, że wspomina się o nich niejako mimochodem, «na stronie»" (Zgółka, 2009, s. 25). Tak też dzieje się w przypadku tekstów po śmierci Piłsudskiego. Świadomość zakazu podejmowania niektórych tematów sprawiła, że bardzo często sięgano po konstrukcję zdania współrzędnego przeciwstawnego - „Jest tak a tak, ale (...)” („Nie poruszając nad trumną Zmarłego Wodza Narodu żadnych spraw politycznych, trzeba jednak stwierdzić (...) oto genjusz Pierwszego Marszałka przejawiał się w takiem właśnie kierowaniu sprawami państwa, że gdy dziś zabrakło Go, to próżnia, jaka powstała nie grozi jednak katastrofą" [IKC, 16 maja].

\section{O czym nie można było mówić nad otwartą trumną?}

Przede wszystkim o przewrocie majowym i autorytarnym okresie rządów marszałka. Autorzy tekstów starali się unikać słowa „,dyktatura” (zarówno w prasie prorządowej, jak i narodowej czy ludowej), a jeśli już się ono pojawiało, to zabiegi eufemistyczne polegały na rozmywaniu negatywnych konotacji: „,dyktator Polski nie narzucający swej władzy gwałtem” [IKC, 16 maja]; ,Dyktatura Marszałka, która w dziejach Polski przedstawia 
jedynie skupienie pełni władzy w ręku jednego człowieka (...)” [,„Kwartalnik Historyczny”]; „Ustąpienie w grudniu 1922, po wejściu w życie Konstytucji marcowej i cofnięcie się do wojska, a później do dworku sulejowskiego. Wreszcie zaś - rok 1926 i od niego epoka, którą obecnie żyjemy" [ABC, 14 maja]. Sam przewrót majowy eufemizowany był jako czyn i to czyn konieczny: „Chaos i rozprzężenie panujące w państwie nakazują Wodzowi Narodu czyn. Czyn ten podejmuje 12 maja 1926 r." [IKC, 15 maja].

Wpisanie działań marszałka w imperatyw historyczny, a nie indywidualny, pozwalało usankcjonować nałożone tabu. W prasie wszystkich opcji dominowało przeświadczenie o niemożności obiektywnego rozliczenia decyzji Piłsudskiego przez jemu współczesnych - odpowiadał on, niemal jak królowie polscy, przed Bogiem i Historią: „Nad otwartą mogiłą walka się kończy, a sądy obejmie historja” [GR, 19 maja]; „,Dyktatura Marszałka (...) sama będzie stanowiła przedmiot dociekań (...)” [, Kwartalnik Historyczny”]; „,Męża, którego czoło ręka Boska naznaczyła stygmatem wielkości" [IKC, 16 maja] czy bardzo ciekawy tekst, w którym autor „ożywia” zmarłego, wkładając w jego usta następujące słowa: „Kazałeś mi Panie cierpieć dla narodu mojego (...) znosić obelgi wrogów, i uczyniłem to wedle najlepszej swojej woli. Kazałeś mi Panie naród prowadzić po szlakach niepodległości, karać jego grzechy, poskramiać nieprawości i uczyniłem to wszystko." [Ś, 19 maja]. Na marginesie warto dodać, że w kontekście Boskiego planu wobec losów marszałka bywał on ukazywany jako Chrystus (vide: poprzedni cytat) lub Mojżesz (poprzez nawiązania do wyprowadzenia narodu z niewoli), a styl naśladował styl biblijny, np. „,wywiódł swe dzieci z krainy niewoli, doprowadził do ziemi obiecanej i widząc swe dzieło umocnione, innym swą pieczę nad niem powierzył" [IKC, 18 maja].

Sam stosunek Piłsudskiego do religii i kościoła także stanowił tabu - w żadnym tekście nie pada informacja o zmianie wyznania i zawiłościach osobistych relacji z pierwszą żoną. Skupiono się natomiast na znaczeniu bitwy z 1920 r. („Duchowieństwo odprowadziło na wieczny odpoczynek Tego, co Chrześcijaństwo przed najazdem pogańskim obronił” [gazeta I pułku lotniczego z 1935 r.; tytuł nieznany]) lub poprawnych stosunkach z kościołem w życiu oficjalnym (autor artykułu w „Gościu Niedzielnym” dwa akapity poświęca informacjom o śmierci, a kolejne cztery podkreślaniu zasług marszałka w eksponowaniu roli Kościoła w nowym państwie i budowaniu „,harmonijnej współpracy pomiędzy Państwem i Kościołem” [„Gość Niedzielny”, 19 maja]). Omijając drażliwy temat czasowej zmiany wyznania na ewangelicko-augsburskie i powrotu do wyznania katolickiego oraz dość nieortodoksyjnej religijności marszałka, podkreślano kult, jakim otaczał Matkę Boską Ostrobramską - pochowany został z jej ryngrafem, a gazety przedrukowywały wizerunki wileńskiej Madonny. 
Szczególnym przejawem cenzury zewnętrznej, ale tym razem instytucjonalnej, była uchwalona w trzy lata po śmierci Piłsudskiego Ustawa z dnia 7 kwietnia 1938 r. o ochronie imienia Józefa Piłsudskiego, Pierwszego Marszałka Polski ${ }^{4}$, składająca się z zaledwie czterech aktów i będąca jedyną tego typu ustawą w historii polskiego prawodawstwa. Art. 1. tej ustawy brzmi: „Pamięć czynu i zasługi JÓZEFA PIŁSUDSKIEGO - Wskrzesiciela Niepodległości Ojczyzny i Wychowawcy Narodu - po wsze czasy należy do skarbnicy ducha narodowego i pozostaje pod szczególną ochroną prawa”. Za ,uwłaczanie imieniu Józefa Piłsudskiego" groziła kara pozbawienia wolności nawet do 5 lat.

\section{Przemilczenie}

Na koniec chciałabym jedynie zasygnalizować kwestię całkowitego zamilknięcia w obliczu śmierci. Ilustruje go odnotowane przez „Gazetę Warszawską” milczenie „Robotnika” ( $w$ ramach rubryki przedrukowującej głosy prasy). Sam fakt dokonywania takich przedruków świadczy o tym, że poza zakazem mówienia o śmierci w określony sposób oraz poruszania określonych tematów, istniał także odgórny „,nakaz” mówienia według norm tego, co dopuszczalne. Całkowite milczenie postrzegane było jako coś niewłaściwego (i dlatego koniecznego do odnotowania) lub wręcz negatywnego - nie jako milczenie, ale przemilczenie.

\section{Zakończenie}

Omawiane powyżej zabiegi eufemizacji i tabuizacji w planie treści mają wyraźnie retoryczny charakter. Wynika to w dużej mierze z charakteru tekstów stanowiących bazę materiałową - przynależą one bowiem do stylu dziennikarsko-publicystycznego polszczyzny i niejako definicyjnie zawierają w sobie elementy perswazyjne. Prasa znajduje się ponadto w szczególnej sytuacji, ponieważ podlegając normie i tabu (a także cenzurze społecznej), zarazem sama je kształtuje, co wyrażane jest zarówno eksplicytnie: „(...) dziennikarstwo polskie ma obowiązek zachowania się godnego, odpowiadającego jej [żałoby - M.R.] doniosłości i powadze" [Cz, 17 maja], jak i implicytnie - wystarczy prześledzić zmiany w zakresie tytułów pojawiających się w tygodniu żałobnym. Przebiegają one od tytułów informacyjnych, poprzez biograficzno-wspomnieniowe (niekiedy wręcz

\footnotetext{
${ }^{4}$ Internetowy System Aktów Prawnych, http://isap.sejm.gov.pl/DetailsServlet?id=WDU19380250219 [dostęp z dnia 26.09.2013].
} 
hagiograficzne), a następnie retoryczno-perswazyjne, by znów powrócić do informacyjnych, odpowiadając, zdaje się, kolejnym etapom przeżywania żałoby, mającym prowadzić do tzw. całkowitego „uniesienia tabu” (termin za: di Nola, 2006), tzn. zaakceptowania śmierci oraz powrotu do normalności. Nie tylko kształt językowy, ale także rozkład procentowy miejsca zajmowanego przez temat śmierci i żałoby na łamach gazet obrazuje kolejne fazy - od poświęcenia temu faktowi całych numerów, poprzez stopniowe ograniczanie informacji, wprowadzanie wiadomości ze świata i pozostawienie specjalnej rubryki „Po zgonie Marszałka Piłsudskiego”, aż do przeniesienia ciężaru zainteresowania na sprawy bieżące i tych, którzy pozostali. Oczywiście, prasa prorządowa i opozycyjna (zwłaszcza narodowa) różnią się w tym względzie znacząco, co odnotowuje „ABC” z 18 maja: , Inne pisma obozu rządowego poświęcają swe rozważania nadal wyłącznie osobie zmarłego Marszałka. W ciągu dni najbliższych jednak należy oczekiwać wypowiedzenia się także $z$ ich strony [w kwestii powstałej sytuacji politycznej - M.R.]. Redaktorzy tworzyli zatem swoisty „,wzorzec” przeżywania żałoby proponowany społeczeństwu.

\section{Bibliografia:}

Allan, K., Burridge, K. (2006). Forbidden Words: Taboo and the Censoring of Language. Cambridge: Cambridge University Press.

Dąbrowska, A. (2009). Zmiany obszarów podlegających tabu we współczesnej kulturze. Język a kultura, t. 21, s. 173-196.

Dąbrowska, A. (red.). (2009). Język a kultura, t. 21.

Dąbrowska, A. (1993). Eufemizmy współczesnego języka polskiego. Wrocław: Wydawnictwo Uniwersytetu Wrocławskiego.

Di Nola, A. M. (2006). Tryumf śmierci. Antropologia żałoby. Kraków: Towarzystwo Autorów i Wydawców Prac Naukowych Universitas.

Eliade, M. (1966). Traktat o historii religii, tłum. J. Wierusz-Kowalski; oprac. B. Kupis; słowo wstępne L. Kołakowski, Warszawa: Książka i Wiedza.

Encyklopedia językoznawstwa ogólnego. (1999) (1993 wyd. I), pod red. K. Polańskiego, Wrocław: Zakład Narodowy imienia Ossolińskich.

Freud, Z. (1993). Totem i tabu, tłum. J. Prokopiuk, M. Poręba; oprac. R. Reszke. Warszawa: KR. Jasik, A. (2009). Tabuizowanie tematu śmierci i realiów z nią związanych w różnych kręgach środowiskowych Opolszczyzny. Język a kultura, t. 21, s. 175-195.

Leszczyński, Z. (1988). Szkice o tabu językowym. Lublin: Redakcja Wydawnictw KUL.

Słownik eufemizmów polskich, czyli w rzeczy mocno, w sposobie łagodnie. (1998). pod red. A. Dąbrowskiej, Warszawa: PWN.

Szymoniak, K. (2009). Tabuizacja polityczna w polskich mediach po 11 września 2001 roku (wprowadzenie do problemu). Język a kultura, t. 21, s. 105-115. 
Tyrpa, A. (2009). Losy słowa tabu w Polsce (od encyklopedii Orgelbranda do prasy popularnej). Język a kultura, t 21, s. 13-23.

Władyka, W. (1988). Prasa Drugiej Rzeczypospolitej. W: J.Łojek, J. Myśliński, W. Władyka, Dzieje prasy polskiej, Warszawa: Interpress.

Zgółka, T. (2009). Retoryka tabuizacji. Język a kultura, t. 21, s. 23-31.

\section{Wykaz skrótów:}

\section{Czasopisma}

$A B C \quad-, A B C$ : nowiny codzienne”

$\mathrm{Cz}-$ - „Czas”

EJO - Encyklopedia językoznawstwa ogólnego, 1999 (1993 wyd. I), pod red. Kazimierza Polańskiego, Wrocław.

GP - „Gazeta Polska”

GW - „Gazeta Warszawska”

IKC - „llustrowany Kurier Codzienny"

$\mathrm{KCz}-$ - „Dobry wieczór - Kurier Czerwony”

KP - „Kurier Poranny”

KW $\quad-$ „Kurier Warszawski”

R - „Robotnik”

Ś - „Światowid”

\section{Słowniki}

SJP War.- Słownik języka polskiego, red. J. Karłowicz, A. A. Kryński, W. Niedźwiedzki, t. 6, Warszawa 1952-1953.

SJP Dor. - Słownik języka polskiego, pod red. Witolda Doroszewskiego [dostęp online: www. doroszewski.pwn.pl]

WSJP - Wielki słownik języka polskiego [dostęp online: www.wsjp.pl]

\section{Summary:}

This article discusses issues concerning press text taboo during the national days of mourning after Józef Piłsudski's death. The source of the material are texts printed in the daily press dated 13.05-19.05.1935. The article discusses both taboo on the formal plane (euphemisms of death and its various aspects), and taboo on a semantic plane (taboo subjects), as well as relationship between taboo and censorship (individual and institutional/public). Its aim is to collect and to analyse euphemisms connected with mourning in the press discourse

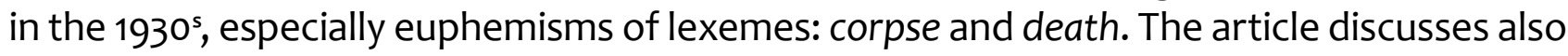
the rhetorical function of taboo subjects defined in connection with Marshal Piłsudski's death.

\section{Keywords:}

taboo, mourning, press $1930^{\text {s, }}$, euphemism, censorship 


\section{Streszczenie:}

Artykuł omawia zagadnienie tabu w czasie żałoby narodowej po śmierci Józefa Piłsudskiego. Materiał stanowią teksty prasowe drukowane na łamach dzienników (zróżnicowanych światopoglądowo) w dniach 13.05.1935-19.05.1935 r. Omówione zostaje zarówno tabu w planie wyrażania (eufemizmy śmierci i obszarów z nią związanych), jak i tabu w planie treści (tematy tabu), a także relacje między tabu i cenzurą (wewnętrzną i zewnętrzną). Celem artykułu jest zebranie i analiza eufemizmów związanych z żałobą, szczególnie eufemizmów leksemów trup i śmierć, w dyskursie publicystycznym lat 30. XX w. oraz omówienie retorycznych funkcji tematów tabu wyznaczanych w związku ze śmiercią marszałka Piłsudskiego.

\section{Słowa kluczowe:}

tabu, żałoba, prasa lat 30., eufemizm, cenzura 